\title{
$\mathrm{X}$ 線透過の. 基礎的研究 (第2 郝)
}

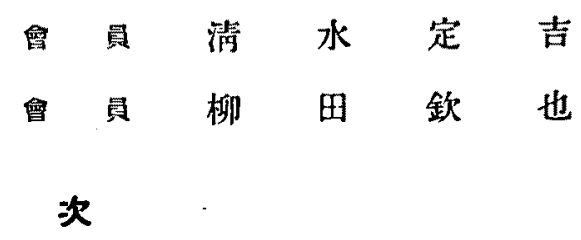

\section{[I] 緒}

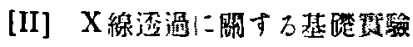

(1) 細い裂目のX線喔滛

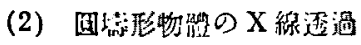

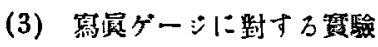

（4）露出曲線確定に對す万實驗

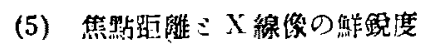

(6) 缺陷制定に閶す万賽驗

(7) X 線殒滑法基得

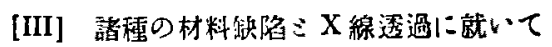

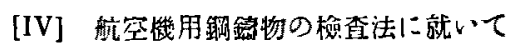

[V] 結喻

\section{[I] 緒 一 言}

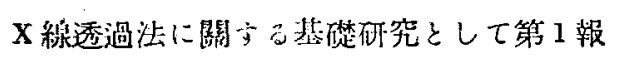

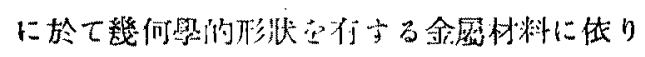

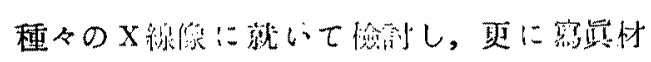

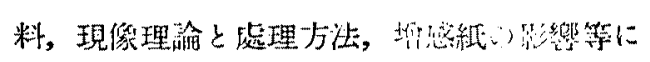

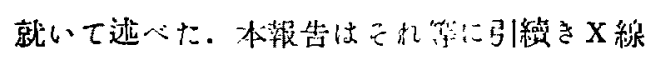

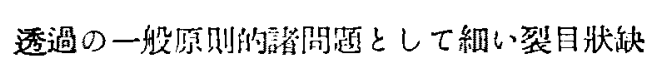

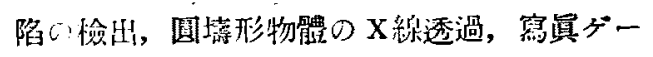

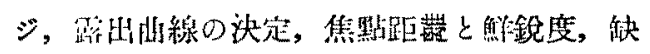

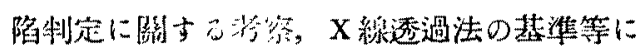
就いて吟味し，更にX線檢查と磁匊試驗・油

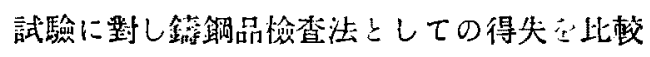
檢討せるものである。

\section{[II］ X 線透過に關する基礎實驗}

\section{（1）細以裂目の X 線透渦}

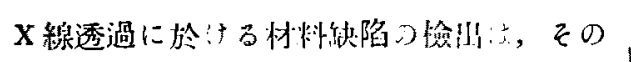

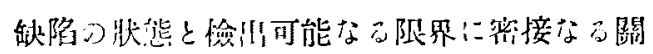

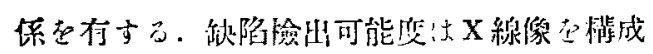

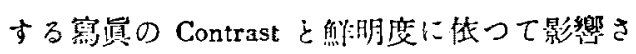

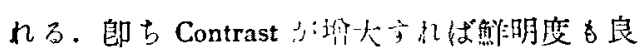

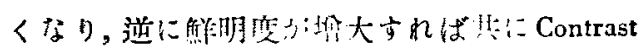

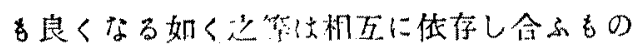
である。而して之籍2つ0現象去夫今生理學

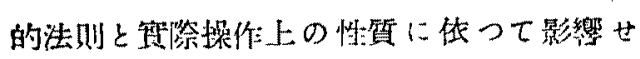
られる。
然るに之篮四おい中で任意に加減し得ざる ものはX線像の Contrastに對して物䯏中の缺

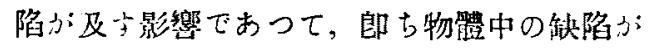

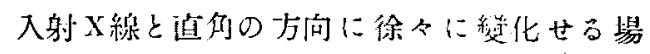
合は，云机に應した缺陷の明带 (Contrast) 。 徐々心愁化子る, 故に 120 明带と他心明帶 との境然が不鮘明になる篇，例人その䊽陷の

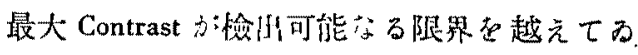

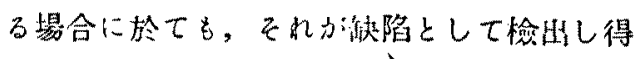

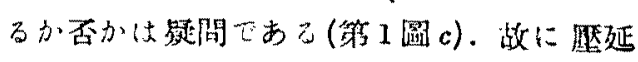
された材料中に存在主っ缺陷のX称透過法困 
第 1 圆
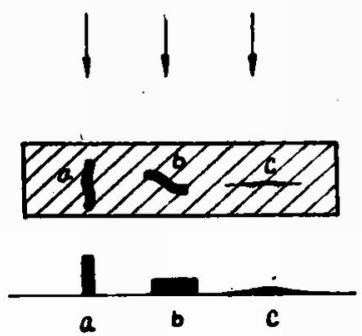

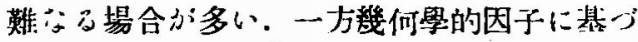
く $\mathbf{X}$ 線集の不薢明がある。光は微細な割れ症 の檢出困難なこ所以にして就中憸山すべき物 體の厚さが大になると页に困難となる。第2

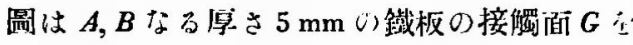

第 2 喝

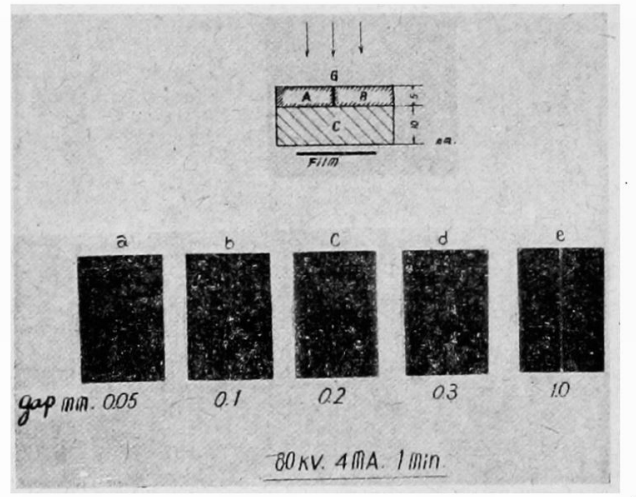

精筑に仕上げたるるのす愿さ $10 \mathrm{~mm}$ の鐵片上

に置き $A, B$ 閒の gap $G$ 空種々變化せる場合り $\mathbf{X}$ 楾像に就いて檢討したものて，賽驗の條件 は電厴 $83 \mathrm{kV}$, 需流 $4 \mathrm{~mA}$ と し, 焦䵞距離 60 $\mathrm{cm}$ に於て各、1 min 透過しだ，感光材料は總 バて富士レントゲンフィルムに堌感紙 2 枚 む作用し，ブレンデは全部使用して居ない。 之に依れば間隙 $0.1 \mathrm{~mm}$ に於汁さ X線像は明

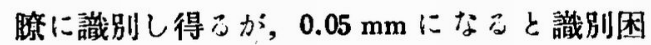
難となる(之等の判定は negative 上肉眼に依 り行ひたるるのにして記载せる反轉弿真にて
沖不明源なる憾ふおるた。

第 3 渴は前記 $A, B, C$ の筫驗試料に依り間 隙に對して物體の厚さが堆加した場合の X線 第 3 圆

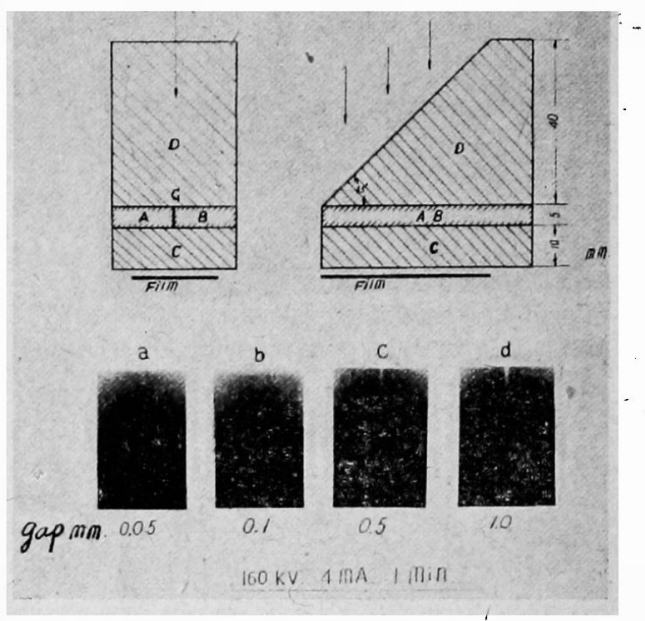

像を憸討した，賽驗方法纺㘣中に示す如く $A$, $B, C$ 上 $D$ なる $45^{\circ}$ の傾斜它もつ鐵片它㯰き間 隙の面に對しては平行にX線透過な行つた (唒電厎電流 $160 \mathrm{kV}, 4 \mathrm{~mA}$ にて焦點距離 60 $\mathrm{cm}$, 露(時間 $1 \mathrm{~min}$ 一定とす). 而して試片 $D$ に對し橫此に各、閒隙の見出し得る最大の $\mathbf{X}$ 楾像の長さ礼以て識别度とし, 前驗と同 樣 negative 上，肉腿に作り之社判定した。 之 等の實驗結果第 1 表に於て示す。郎方間陣

第 1 表

\begin{tabular}{|c|c|c|}
\hline No. & 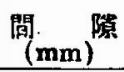 & $\begin{array}{c}\text { 像の誦别度 } \\
(\mathbf{m m})\end{array}$ \\
\hline $\mathbf{A}$ & 0.05 & 0 \\
\hline B & 0.10 & 21 \\
\hline C & 0.50 & 26 \\
\hline D & 1.00 & 28 \\
\hline
\end{tabular}

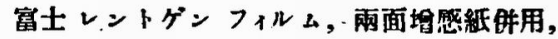
ブレンデ無し.

$0.05 \mathrm{~mm}$ に於て牥そい $\mathrm{X}$ 線像は㱠ど識别し得 ない. $0.1 \mathrm{~mm}$ に於て 解明であるふ識别度は 
小てある, $0.1 \mathrm{~mm}$ 以上の間隙に對しては識別

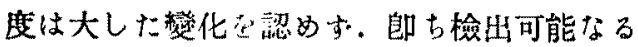

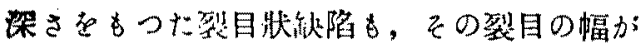
㴍めて傼小になると檢出不可能となる..次に 裂目狀の缺陷は入射 $\mathrm{X}$ 線の方向か檢出可能の 限界に影響する事極めて大である。郎古第 1 圆 $a, b$ よ溚察せらる〉如く裂目の面々入射 $\mathbf{X}$ 線か科行なる場合に最大の結果が得られ ๖. 第 2 表は厚さ $40 \mathrm{~mm}$ の鋼忉中に深さ $6 \mathrm{~mm}$

第 2 表

$\Delta$ 裂目の面ミ $\mathrm{X}$ 線さの閶の角

B 見出得 万裂目の幅 $(\mathbf{m m})$

\begin{tabular}{|c|c|c|c|c|c|c|c|c|c|}
\hline A & $10^{\circ}$ & $20^{\circ}$ & $30^{\circ}$ & $40^{\circ}$ & $50^{\circ}$ & $60^{\circ}$ & $70^{\circ}$ & $80^{\circ}$ & $90^{\circ}$ \\
\hline B & 0.10 & 0.20 & 0.25 & 0.30 & 0.33 & 0.37 & 0.38 & 0.40 & 0.42 \\
\hline
\end{tabular}

Fe の厚? $40 \mathrm{~mm}$

裂目の深さ $6 \mathrm{~mm}$

なる裂目について入射X秋の角度と見出し得 る裂目の最小の幅を檢討せるものの結果にし $\tau$ ，入射 $\mathrm{X}$ 線と裂目の面との成主角度か: $20^{\circ}$ なるとき檢出し得る最小の裂目の幅は $0.2 \mathrm{~mm}$

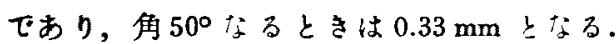
斯樣に割れ疵の憸仙は裂目の面に對し入射 $\mathbf{X}$ 楾の方向は $90^{\circ}$ 些域として大となり又は小と なるに從つて堽大し，裂目の面と入射X線の 成与角か：00 又は $180^{\circ} に$ 於て最大となる。一

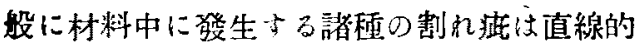
に進展せるるの少く，その殆どが曲折して 居り，透過に際し人射 X線と幾分加の角㔖生

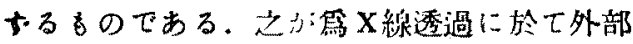
上り缺陷の觀察可能なる8のは容易である か，完全なる內部的割れ疲の檢出は困難で あъ.

\section{（2）回塼形物體の X 線透過}

圆墙形物體 (pipe) は外觀的には形呮簡單な

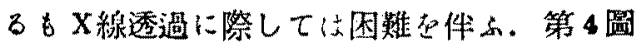
第 4 喝

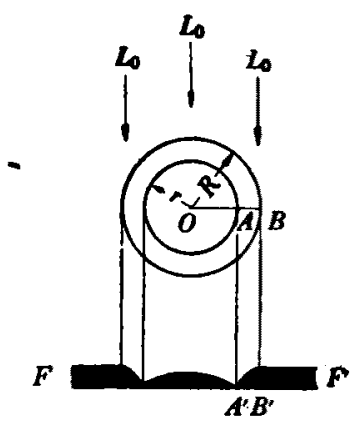

に於て外徑 $2 R$, 內徑 $2 r$ ハハイプを $F F^{\circ}$ に フィルを置いてX線透過存行つた場合，ハ イプの各㲅分に於汁るX楾の通過した啳のX 線量は各部分に位つて異なる。郎ち $A$ 點に於 ては肉厚最を大にして $2 \sqrt{R^{2}-r^{2}}$ であり，B 點に至ると○となる. 中心 $O$ から $O B$ 上 $x$ の 距離に於ける各厚さは $2 \sqrt{R^{2}-x^{2}}-\sqrt{r^{2}-x^{2}}$ である故に，フィルム $F F^{\prime}$ 上の $A$ 點に當る $\mathrm{X}$ 線は最も厚い部分で吸收せられる爲, 透過 $\mathbf{X}$ 楾は少量であるがB黙に於ては甚げ多量のX が當る、斯樣にしてパイプのX線透過に於

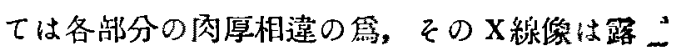

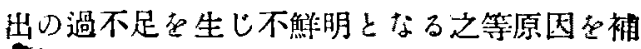
今篇，5圆に示す如く無㾟の同質の材料に

第 5 圆
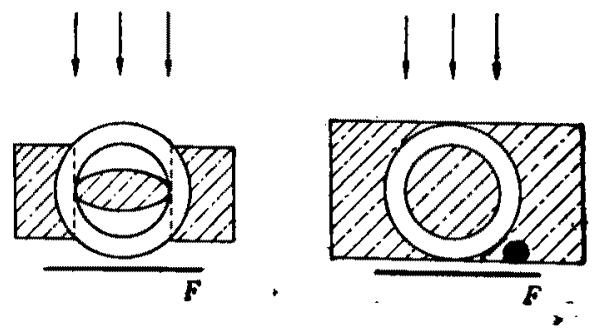
低り充境し厚さ均等にし $2 R$ 又は $2 \sqrt{R^{2}-r^{2}}$ の板にして X線透過行等事出出來る. 然心 に實際上に於ては圓堬形物體には徑及び肉厚 の大小，又は交文せるもの等その種類形狀は
椱雜多岐敕極め, 從つて之等に對し種々の埋 金发常蒈適用する事は甚げ煩雜であり且肉厚 の增大に依り檢出可能度を減少せしむる等， 種々の不都合む生する。

第 6 潤

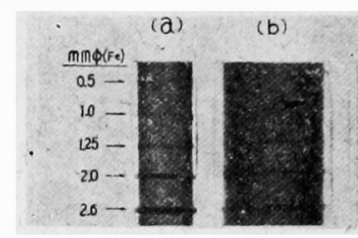

第6 圖は埋金芯使用せざる場合に於ける 種々肉厚及び直徑の異なるパイプな透過し

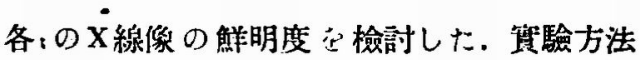
は第７闾に示す如く各、のバイプの上に寫真
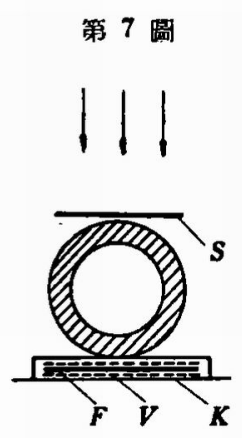

$$
\begin{aligned}
& S=\text { スケール } \\
& F=フ イ ル ~ \\
& V=\text { 增感紙(2 枚) } \\
& K=\text { カセット }
\end{aligned}
$$

スケール $(0.5,1.0,1.25,2.0,2.6 \mathrm{~mm} \phi \mathrm{Fe})$ 官 置き適切條件なるX線にて透過し，そのX線 像中に於て見川し得さスケールの像の長きる 徑との關係に就いて吟味した。第 3 表はこれ 等の實驗結果走示す. 郎真缜圖に依り考察

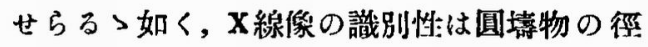
に關係心 く肉厚少大になると減少する。肉厚 か５ mm 以上になる上物體外部よりのカブり
(C)

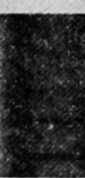

\begin{tabular}{|c|c|c|c|c|}
\hline \multirow{2}{*}{ No. } & \multicolumn{2}{|c|}{ バイブ形狀 } & \multirow{2}{*}{$\begin{array}{c}\text { 見出し得る } \\
\text { 針金の太さ } \\
(\mathbf{m m} \phi) \\
\end{array}$} & \multirow{2}{*}{$\begin{array}{c}\text { パイブ影像中 } \\
\text { の針金の長さ } \\
(\mathrm{mm})\end{array}$} \\
\hline & $\begin{array}{l}\text { 外徑 } \\
\mathrm{mm}\end{array}$ & $\begin{array}{l}\text { 肉厚 } \\
\mathrm{mm}\end{array}$ & & \\
\hline $\mathbf{a}$ & 19 & 1 & 0.5 & 16.0 \\
\hline b & 34 & 3 & 0.5 & 24.5 \\
\hline c & 42 & 5 & 0.5 & 23.0 \\
\hline d & 41 & 3 & 0.5 & 32.5 \\
\hline e & 48 & 10 & 1.0 & 22.0 \\
\hline
\end{tabular}

(d)

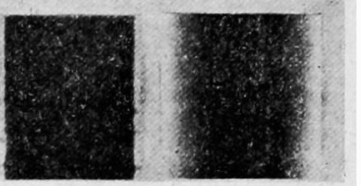

第 3 表

が侵入し圆㙴物體队徑部分の解明度は著しく

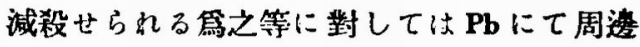
部䓃被ひ曝射き防止すべきである，第8圖は 二,三の阅境形物體の透過法と，その效用につ いて示したものであこ。(A) は直徑並びに肉厚 の小なる物體け一般的透過法にして，摄影は $90^{\circ}$ 物體さ间轉し 2 回の放射走要する. 然し そのX線像永上下の肉原部が重椱する篇, 缺 陷存在位置の判定は確實支期し難い（B）は 肉厚・俓共に大なる物體の撮影方法にして フィルムの固定は装置に附隨せる電磁石又は その他の片法に依り行心。撮影司數す任意で あり觖陷位置の制定も碓實であるガスボン ぶ・水厴管路・ガス反應塔等の材料缺陷及び熔 接斷目の缺陷檢查に適切である. (C) は肉厚 僅小にして徑も比較的小なる物體, 例へば 
(A)

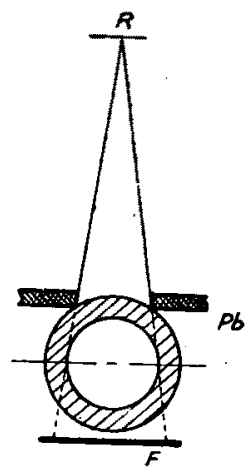

(B)

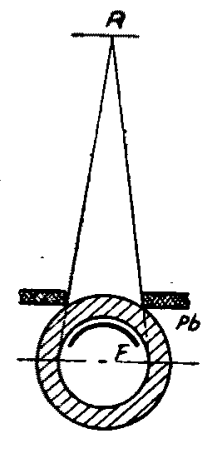

第 8 圆

(C)

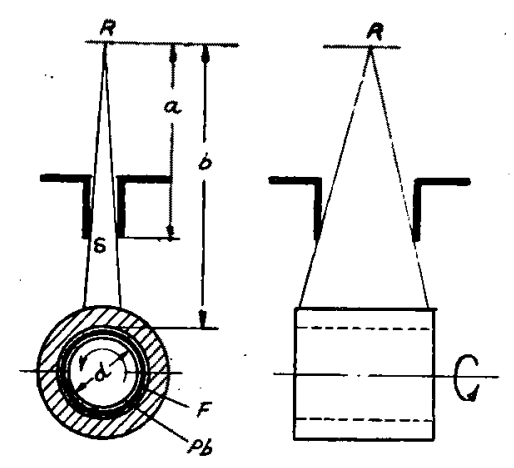

氣管詷等の大量的憸查に利肘せられる1方

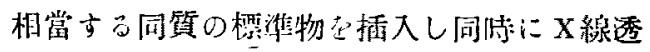

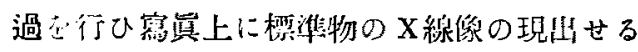

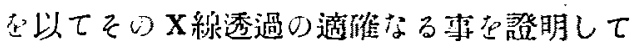

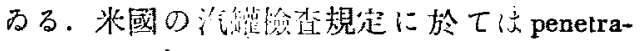

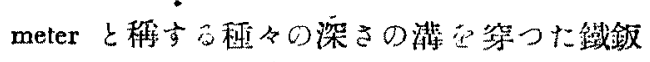

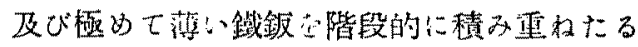

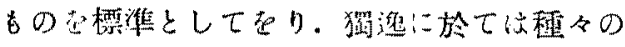
太さの巽なる7机の针全ずム板中に摤んだ

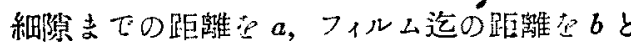
すへば,フフィムF洁 $t=S \times b / a$ の幅のX楾 を受ける，然るに圆箖の直徑をるとすれば， 圆葶か静止せる場合と备缚せる場合のフィル ムの受けるX線罪の此は $\pi d: t$ となり從つて

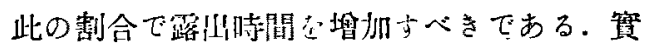
驗的寛例に低机ば領止せる場合の一般的撮影

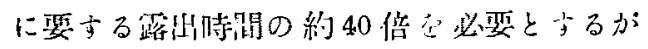

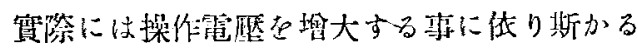

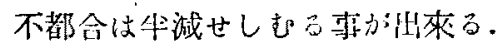

\section{（3）寫窅ゲージに對する實驗}

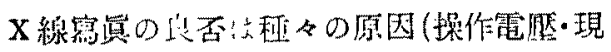
你處理の邀否)に低つて定まる。それに位り

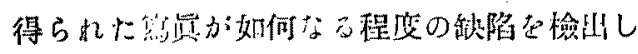
得たか登明する第物體の厚さの 2〜3\%に

一もの標準としてるる。等花熔接部及びを の他の被試材上に置き同時に撮影し竄真上に 於て物體の $2 \%$ 久はをれ以下の厚さの差に相

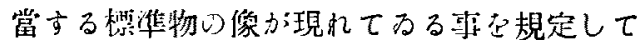
るる。

$\mathrm{X}$ 線憸查に於て操作の最も優秀なる場合に 檢出し得る取小の觖陷は物體の厚さに對する $2 \%$ と云去れてるるか，一般に1枚のX楾寫 真の現し得る缺陷の程度心 $\mathrm{X}$ 線撿查に際し操 作の㕍劣，物體の厚さ，感光材料及び现係處

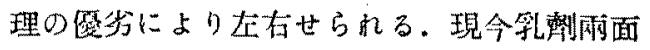
鉒布のレントゲンフィルムの入衔困難なる

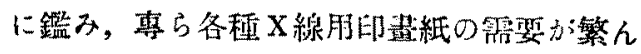
になつた，先に本報告第 1 故に於てX線透過 
值接撮影に適するものとして Oriental X-ray: paper (OX) と. Fuji Bromide paper (FB). . 2 㮔 る舉け゚た．之等に對し檢出し得方最小檤を检 討し更に一般 $\mathrm{X}$ 線檢查時に寫真方ージとして 利用す心゙き標準物の規潐占决定した。.

假定的舁真グージとして，第 9 䔽 (A)に す如き7本の針金型のもの使用した．同

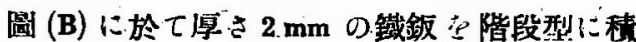
み重ね，之とカセットの間に第真ゲージ踭 入し種々條件を變化せしめて $\mathbf{X}$ 線透過を行つ” た. 第 10 圖及び第 4 表は之等の結果亦々も ので各、の放射電麽に於て透過可能なる Fe 厚さと見出し得る最小厚さの美(寫真方ージ の肉眼的判别) 希兩者に就いて檢討した。㓝 ち兩者の概略的得失异述ぶれば OX は透過 に對する感光度優秀にして最大 $200 \mathrm{kV}$ に於 $\tau 42 \mathrm{~mm}$ (Fe厚) 透過し見出し得る最小厚さ
第 10 粗

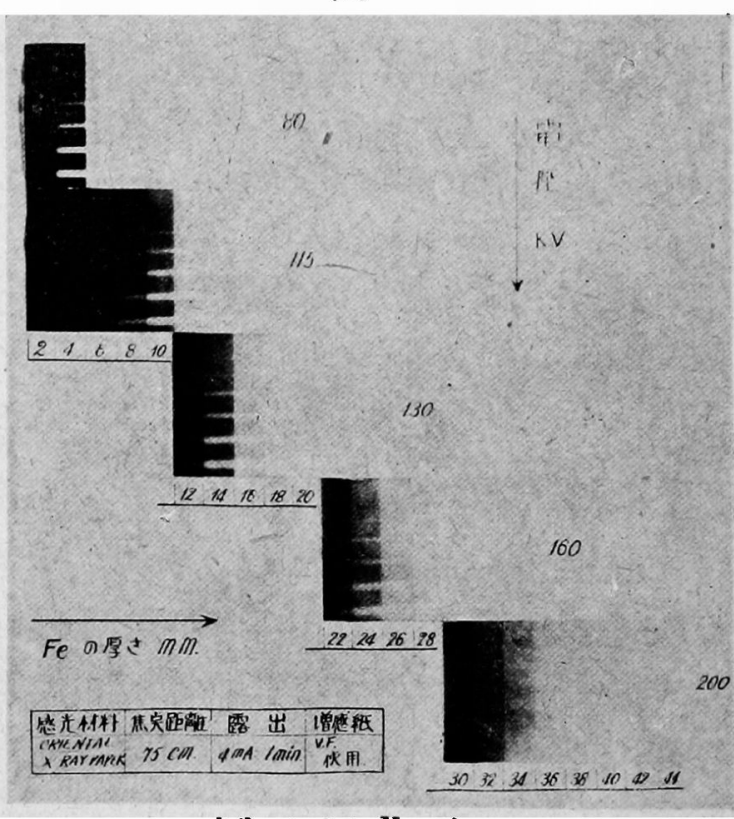

第 9 四

(A)

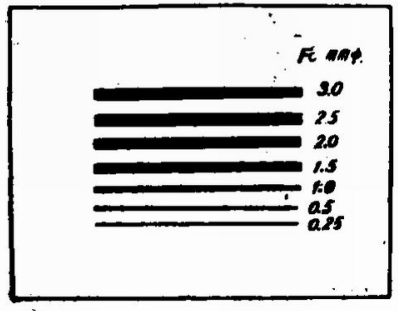

假定蔫峷スケーール

(B)

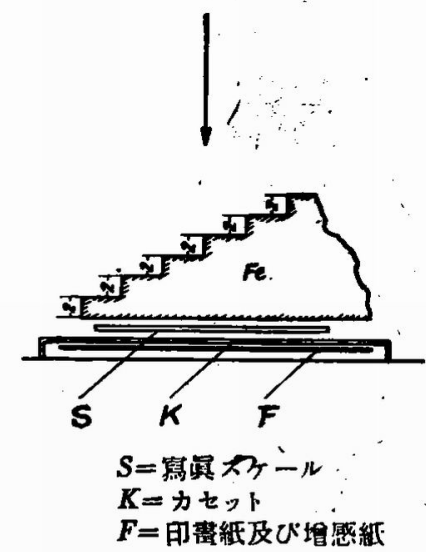

.(A)

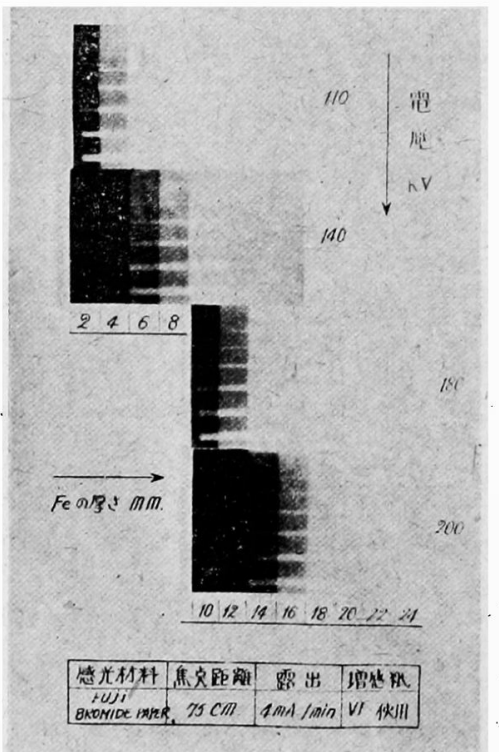

富士プローイド

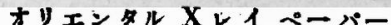


(A)

富士ブロマイト

\begin{tabular}{|c|c|c|c|c|}
\hline \multirow{2}{*}{$\begin{array}{l}\text { 電臂 } \\
(\mathrm{kV}) \\
\end{array}$} & \multirow{2}{*}{$\begin{array}{c}\text { 簬出 } \\
\text { (mA.sec) }\end{array}$} & \multirow{2}{*}{ 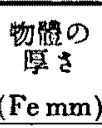 } & \multicolumn{2}{|c|}{ 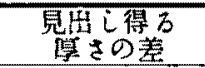 } \\
\hline & & & 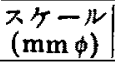 & $\%$ \\
\hline \multirow{3}{*}{110} & & 2 & \multirow{4}{*}{0.25} & 12.6 \\
\hline & 240 & $4-$ & & 6.3 \\
\hline & & $6=$ & & 4.2 \\
\hline \multirow[b]{2}{*}{140} & \multirow[b]{2}{*}{240} & \multirow{2}{*}{$\begin{array}{c}8 \\
10- \\
12\end{array}$} & & 3.1 \\
\hline & & & \multirow{4}{*}{0.5} & 5.0 \\
\hline \multirow{3}{*}{180} & \multirow{3}{*}{240} & 14 & & 3.5 \\
\hline & & $16-$ & & 3.1 \\
\hline & & $18=$ & & 28 \\
\hline \multirow{3}{*}{200} & \multirow{3}{*}{240} & 20 & \multirow{3}{*}{1.0} & 5.0 \\
\hline & & $22-$ & & 4.5 \\
\hline & & 24 & & - \\
\hline
\end{tabular}

其の他仗露出の滑不足に:伐り不明等なるしの 縓べて焦點距踓 $75 \mathrm{~cm}$, 增感紙使用, ブレンテ 無 $乞$.

の差は $130 \mathrm{kV}$ に於引る $\mathrm{Fe} 20 \mathrm{~mm}$ に對し 2.5 \%であつた。 FB 绞最大 $200 \mathrm{kV}$ に於て $24 \mathrm{~mm}$ ( Fe 厚) 透渦し, 見出し得る最小厚さの差 は，180 kVに於けるFe $18 \mathrm{~mm}$ に對し $2.8 \% て ゙$ あつた，份各部分の傒の Contrast は後者方特 に唀れてある。而して之等の筫羷結果に依 ク, 被检查品の济厚と插入すべき針金型竄真 ダージ决定し筫查に適用してるる(第 8 表1).

\section{（4）露出曲線確定に對する實驗}

$\mathbf{X}$ 線透過に於て沙陷の識别可能度に影響艺 及す囚子は 1) 二次 X線の影響，2）幾何學 的原因に依る影饗，3）過剩電笑に依る影響 等でるが，3）に起因する像の不解明は
(B)

\begin{tabular}{|c|c|c|c|c|}
\hline \multirow{2}{*}{$\begin{array}{l}\text { 電暦 } \\
(\mathrm{kV})\end{array}$} & \multirow{2}{*}{$\begin{array}{c}\text { 䇴出 } \\
\text { (mA.sec) }\end{array}$} & \multirow{2}{*}{ 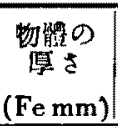 } & \multicolumn{2}{|c|}{ 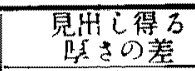 } \\
\hline & & & $\begin{array}{c}\text { Rケ-ル } \\
(\mathrm{mm})\end{array}$ & $\%$ \\
\hline 80 & 240 & $\begin{array}{l}2 \\
4- \\
6=\end{array}$ & 0.25 & $\begin{array}{r}12.6 \\
6.3 \\
4.2\end{array}$ \\
\hline 115 & 240 & $\begin{array}{c}8 \\
10 \\
12\end{array}-$ & \multirow[b]{2}{*}{0.5} & $\begin{array}{l}6.3 \\
5.0 \\
4.2\end{array}$ \\
\hline 130 & 240 & $\begin{array}{l}14 \\
16 \\
18- \\
20=\end{array}$ & & $\begin{array}{l}3.6 \\
3.1 \\
2.8 \\
2.5\end{array}$ \\
\hline 160 & 240 & $\begin{array}{l}22 \\
24 \\
26 \\
28-\end{array}$ & \multirow[t]{2}{*}{1.0} & $\begin{array}{l}4.5 \\
4.2 \\
3.8 \\
3.6\end{array}$ \\
\hline \multirow[b]{3}{*}{200} & \multirow[t]{2}{*}{240} & $\begin{array}{l}30 \\
32 \doteq\end{array}$ & & $\begin{array}{l}3.3 \\
3.1\end{array}$ \\
\hline & & 34 & \multirow[b]{2}{*}{1.5} & 4.4 \\
\hline & 480 & $\begin{array}{l}36 \\
38 \\
40 \\
42=\end{array}$ & & $\begin{array}{l}4.2 \\
3.9 \\
3.8 \\
3.6\end{array}$ \\
\hline
\end{tabular}

最も著しく缺陷識別や低下まる。文物體の厚

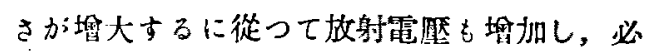
然的に像の Contrast は減少する. 但接法にし て印证紙さ使用する晹合はフィルムに對し寬 容度も小ですり，缺陷判定を白色光にて透視 䠐察し得ない爲, 現像封の黑化度々一定に

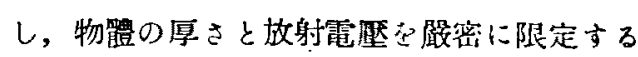
事が必要である，X線透副に於て谷程材料の 透過可能の限界は或程度は任意である。即

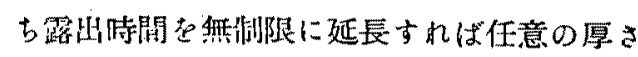
の材料を透過し得る. 然し露出㭙間をどの程 度に許容するかは各、の技術者に依り異なる 
第 11 晴
(A)

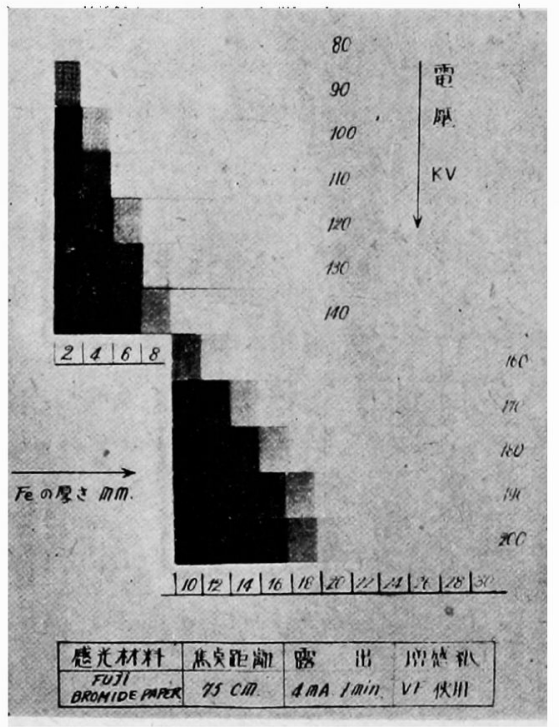

富士プロマイド
(B)

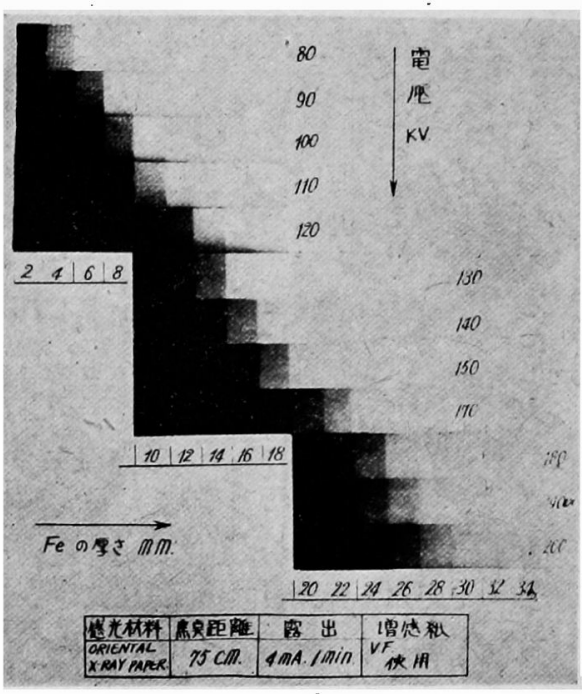

オリエンタル X $\mathrm{X}$ レペーバー
が賽用的には最も迅速に檢出し得る事か至當 てある。

第 11 圆は焦點距離・管球電流・露出時間 莡 一定にし操作電塺のみ㧛化せる場合の Fe 透過度を示す. (A)は Fuji Bromide (B) は Oriental X-ray paper であり，現像時間は總ぐ て液溫 $18^{\circ} \mathrm{C} に て 1 \min 40 \sec$ を標準とした。 而して之に位り各電厭に於て一定（又は近似 的)黑化圭示主部分を探り第 12 圖の如き雨者

第 12 回

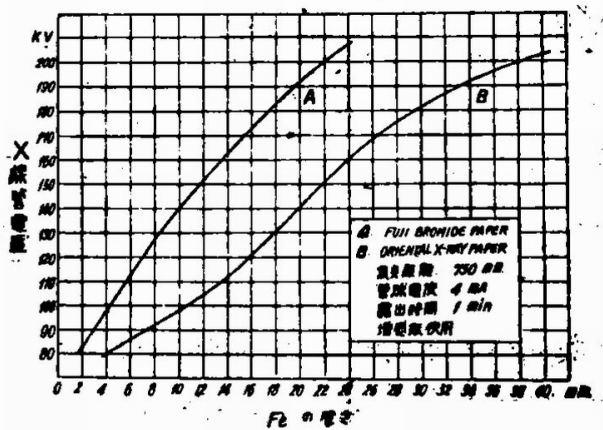

の管出曲線学得た。

X線透過に於ける透過可能の限界は（一定 佟件の X線に於て)感光材料の種類に依り多 大に影響される。局種の感光材料に於ても その新蕉により戀化する雼，直接法にして印 畫紙を使用するX線检查には露出條件を確定 し缺陷檢出の账界を向上せしむる事が旰要で、 あょ.

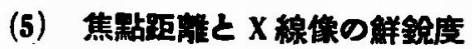

X線透過に於て微細缺陷の檢山文は像の解 銳度垉大する篇の保件は次の如くである゙。

(1) 焦點を小にす。

(2) 焦點距離をな大する。

(3) 物體・フィルム間距離を小にする。 而して之等の中て任意蘩化す召事の出來な くものは(1)であり，之は装置により異なる。

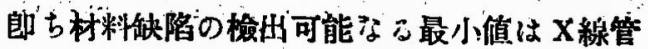


焦點の大いさに依り決定せられる故に检出可 能傎は操作基準の一定なる場合に於ても焦點 の大きさに依りその絕對値は左右せられるす のであるから，检出可能値を知る雼には装置 の焦點の大きさ求め, 然る後その焦點に於 て捡出し得る缺陷の最小值に到達せしむへく

第 13

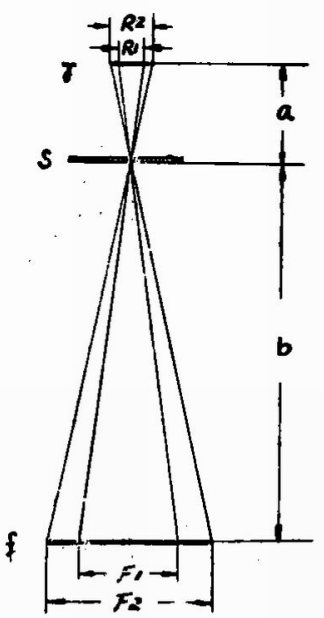

(a)

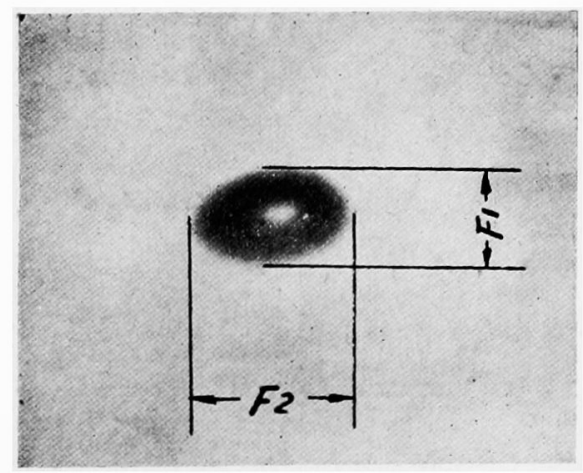

$a=150 \mathrm{~mm}$

$b=380 \mathrm{~mm}$

$E_{1}=10.1 \mathrm{~mm}$

$F_{2}=15.2 \mathrm{zmm}$
操作法の改善及び操作基準を決定すへきであ る. 焦點の大きさを測定する1方法として夫 の如き實驗を行つだ第 13 圆に於て焦點 $\boldsymbol{R}$

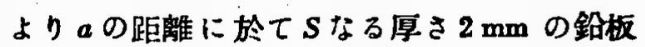
に0.5 mm の孔を第ちたるものを置き, 同 $S$ よりるの距離にフィルムを裝置し一定條件な るX線にて放射すれば針孔䳆遉の理論より管 球放射密直下に於ける焦點の影像を得る。而 して焦點影の縱及び棤の長さ真测し各、 $F_{1}$ 及び $F_{2}$ とすれば焦點 $R_{1}, R_{2}$ は夯の如く算出 ナる事を得る。

$$
\begin{aligned}
& R_{1}=\frac{a}{b} F_{1} \\
& R_{2}=\frac{a}{b} F_{2}
\end{aligned}
$$

第 14 國は嘪驗結果を示すものにして，そ の影像より考察せらる〉如く本装置の焦點は 直徑 $6 \mathrm{~mm}$ の中茎圓形焦點にして焦點直下に 於ける有效焦點影は橫軸 $\left(F_{2}\right) 6 \mathrm{~mm}$ ，縱軸 4 (b)

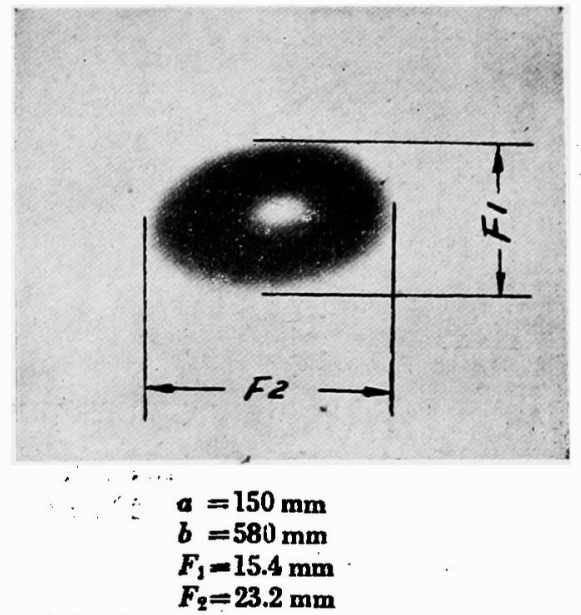

$(60 \mathrm{kV}, 2 \mathrm{~mA}, 20 \mathrm{sec})$ 
$\mathrm{mm}$ の楕圆形焦點となって投影する．头に他 の2つは任意に變化し得るすので（2）は無限 大であるが之に對し露出時間の增大に依り能 率に影響を及す。焦點距離と簬出時間の割合 は距離の 2 非に逆比例して聕隇する. 本装置 の操作可能なる管球霄流, 焦點距離 $と$ 路出㭙 間の割合を第 15 圖に示す，又焦點距離と檢 出可能なる缺陷の割合第 5 表に示した。
第 15 国

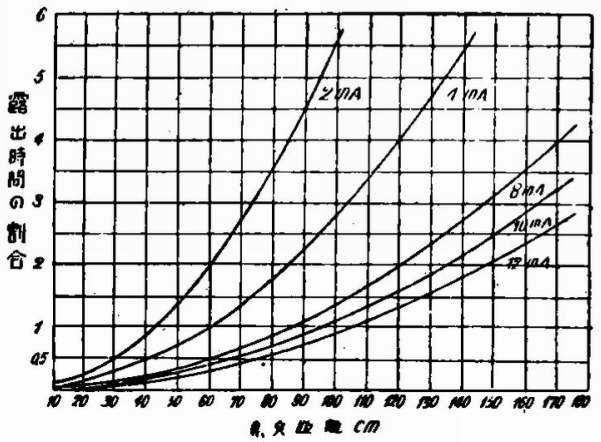

第 5 丧

\begin{tabular}{|c|c|c|c|c|c|c|c|c|}
\hline 焦 點 距 & 30 & 40 & 50 & 70 & 80 & 100 & 150 & - \\
\hline $\begin{array}{c}(\mathrm{cm}) \\
\text { 検出可能最小値 } \\
(\mathrm{mm})\end{array}$ & 0.9 & 0.8 & 0.7 & 0.6 & 0.6 & 0.5 & 0.4 & - \\
\hline
\end{tabular}

（3）の物體・・ィルム間い)距離は物體い形 狀に左右せられる．然し高電壓に於て操作芑 行ふ昜合に物體より散璠する二次 X線な防止 する爲物體・フィルム間にブレンデ及は空氣層
号置く場合は楼分像の鮮釦度は減少するか～ Contrast並びに識別性を良好ならしむる場合 もある.一般的には物能とフィルムは密着せ

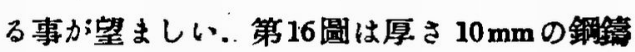

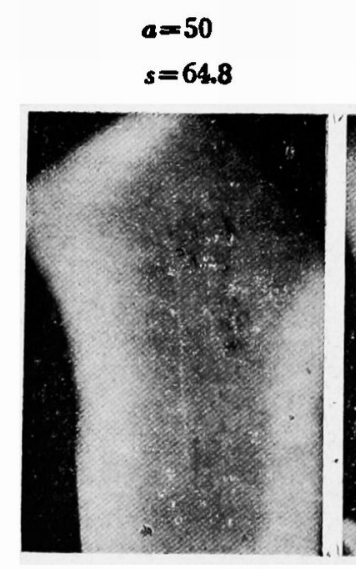

第 16 圆

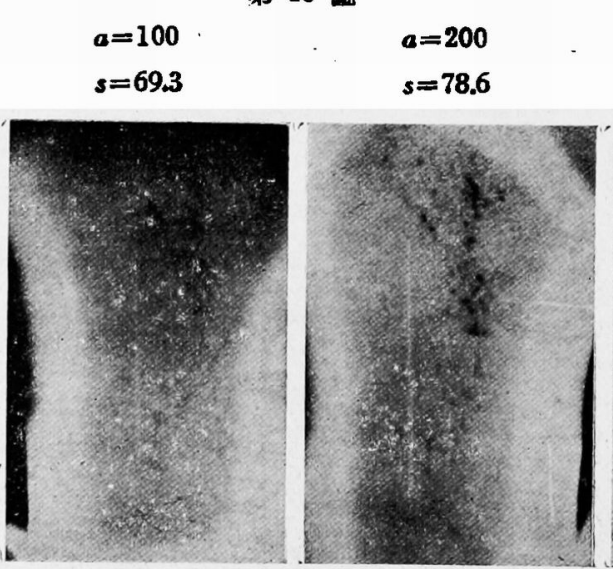

$$
\begin{aligned}
& a=300 \quad \mathrm{~mm} \\
& s=89.2 .
\end{aligned}
$$

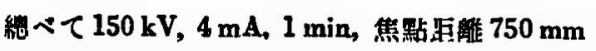

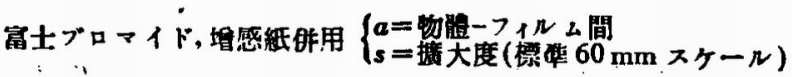

物の缺陷部を，物體・フィルム間郎ち $a$ 莨變化 せる場合の X線像の鮮銳度を检討し, 更にa に對し像の摭大吟味した(っ搌大度とす)。
郎古缺䧄像の蘚銳度は @の坦大と共に低下し $a=200 \mathrm{~mm}$ 以上になると像のボタは著しく 目立つてくる。像の摭大sは 
比例的に睤加する。

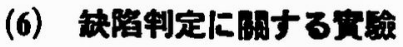

1つの物體中に存在する缺陷を寫真に現れ た X線像の黑化差に伎り之を肉腿的に觀察し その良否る判定する事が最す困難なる問題で ある.X線憸查に於て唯單に缺陷の有無节知 るのみでなく，種々異なる黑化差特った 各、の缺陷像に對して，如何なる大いさ（深 さ）の缺陷であるかを判定する場合は更に熟 達した技術と多大の經驗虎要する.之等缺陷 の寫真上に於ける制定の目安として次の如き 實驗を行つた．第 17 圖に於て厚さ $M$ なる物

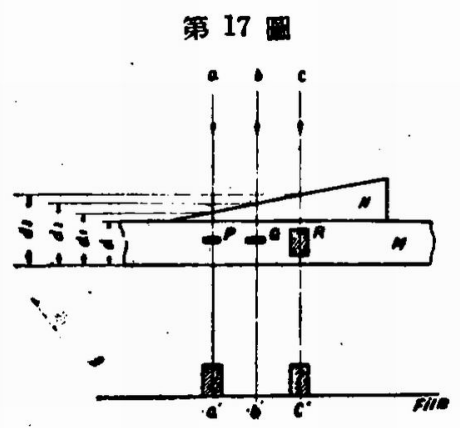

體上に $N$ なる同質の楔型試片を置き一定條件 のX線にて透過した場合, 厚さ山に於て $\boldsymbol{P} な$ る缺陷が竄冥上に或黑さ持つて检出し得 たとすると（此の場合 $d_{1}$ 上母材の缺陷以外の 部分が寫真に㗹する黑さは \pm 0 とす)，厚さ $d_{2}$ なる $b b^{\prime}$ 上に於て $P$ と同し大きさの缺陷 $Q$ は寫㣀に現れない。及 $c c^{\prime}$ 上移なる厚さに 於て $\boldsymbol{P}$ と同し黑さを持つた缺陊 $\boldsymbol{R}$ 得た場 合, 缺陷 $R$ の大きさは $\left(d_{3}-d_{1}\right)+P$ に依り推 定する事方出來る。第 18 圖は此の實驗的實 例を示す，厚さ $10 \mathrm{~mm}$ の鐵鈁に $0.5,1 \sim 7 \mathrm{~mm}$ の㸺を穿ち之に 2 種の楔型鐵鈑を置き一定X 線にて透過しだ.2つの楔に對し，溝の深さ $3 \mathrm{~mm}$ と $7 \mathrm{~mm}$ のすのに就いて, X線像の消失 並びに黑さの一定せる部分の楔の厚さを检討 した。郎ち $A A^{\prime}, D D^{\prime} に$ 於て兩者の X線像は 消失し $B B^{\prime}, C C^{\prime}$ に於て雨者, $\mathrm{X}$ 線像の黑さは 一致した。次に $A A^{\prime}$ の全厚さは $13 \mathrm{~mm}$ であ $\eta, D D^{\prime}$ は $20 \mathrm{~mm}$ であつた. 而して漊を第つた 鐵鈑の厚さ10 mm 䓃各、全厚みより除いたす

第 18 圆

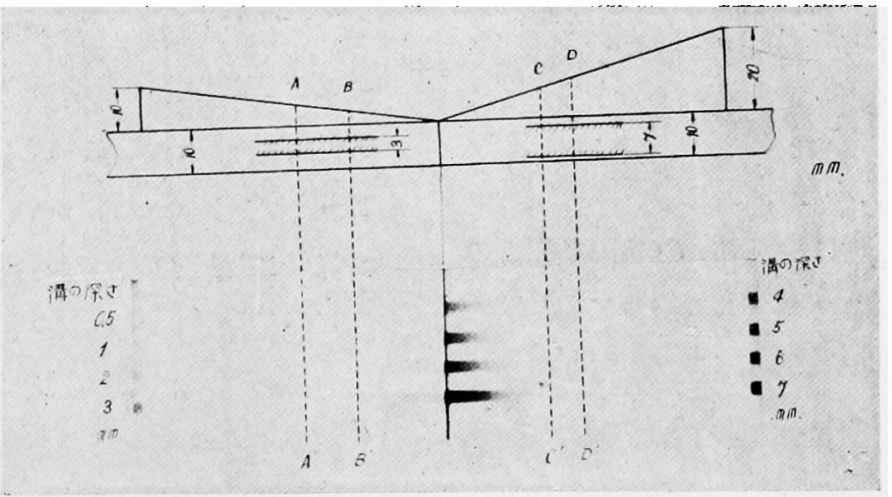

の, 䬦古楔の厚さは各、溝(缺陷)の深さと相當 した, $B B^{\prime}, C C^{\prime}$ は各、黑さの均等なる部分に
してその全厚さは $B B^{\prime}=10, C C^{\prime}=14$ であわ各i 清の深さ除いた全厚さは共れ，等しな結果 
第 19 暗

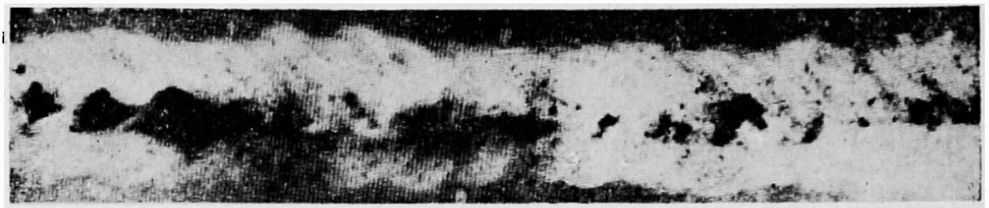

一般的撮影に依万るの

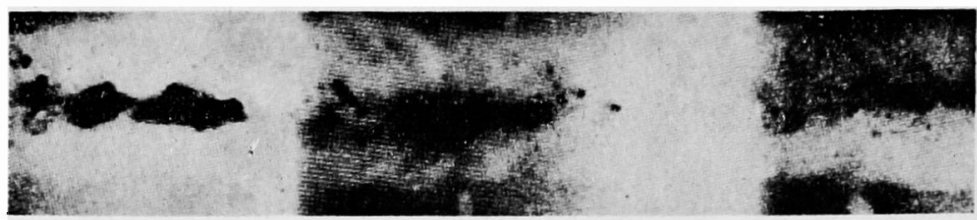

同上位遗に楔型ゲージか遒用さるるの

を得た：第 19 曷は鋼鈑熔接部の缺陷に本方 法寺適用した貝例杂す。而して X線の物質 首に依る減弱を利用し，材料內部の未知なる 缺陷怘緻密に知る事が出來る。第20圖はフィ ルムに依り撮影せる場合の缺陷制定の一方法 にして, Goldberg のデンソグラフの原理に依

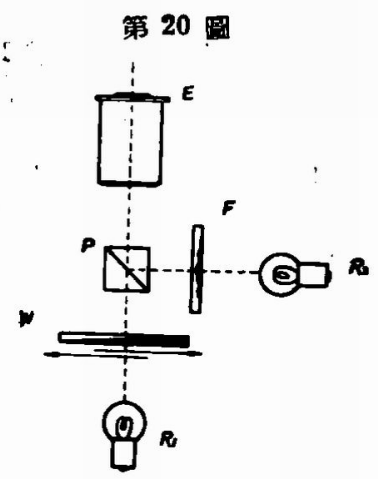

るものである.圖に於て $R_{1}, R_{2}$ は同し强さの 光源にしてPなるプッズムに依つて交り振大 鏡 $\boldsymbol{E}$ に影する。Wは灰色標準楔であり黑さは 無段階的に0より $\max$.に變化して居り此の 黑さの變化に對して一定の目盛が刻まれてる る.而して一定佟件にて撮影現像せられた試 㯺フィルムを占なる位置に裝備する。フィルム
の或 1點(缺陷像)に對しWなる楔を左右に移 動し，黑さの一致せる部分に於て目盛を記録 し夫くの缺降と他の部部 (無疵の部分) との黑 化差を數值的に表し之等の判定を行ふ事が 來る.

\section{（7） X 線透過法㟟涑}

$\mathrm{X}$ 線透過の基礎的研究を完結するに當り第 \報並びに以上本報告の實驗結果より實查に 適用し得る諸條件を總括要約し之をX線透過 の操作基準とした。

[X 線透過法基準]

第1條 裝置ハレザイフェルト・イゾルッタスフ ニシテ全X楾發生容量ハ次ノ如シ。

X 楾管電壓 max. $250 \mathrm{kVP}$

$X$ 線管電流 max. $15 \mathrm{~mA}$

第 2 條 $X$ 線憸查，適用八肉厚 $60 \mathrm{~cm}$ 以下， 鐵・鋼・鋼绎物，又八其，他，金屬材料·非 鐵合金・非金屬材料二適用スルコトタ得. (但シ鐵合金以外、密度二應 シ厚廿モ增加 シ得ル)

第 3 條 鐵・鋼・鎑鋀物， $\mathrm{X}$ 線檢查二於テ使用 スベキ感光材料ハ第6表ニョルモノトス。 
第4佟 各感光材料，現像處理八し富士ブロ マイドフォ除ク，外操作鼠厴 $180 \mathrm{kV}=$ 及 ブトキハ總ベテレコントラスト現像フ $=ヨ ル$ モノトス，其ノ他二於テハ指定現像液二ヨ リ之キ行フ.

第 5 佟 增感紙，適用，第 7 表二依ルモノ卜 ス。但シ習㗹紙 7 使用セザル場合八被撿查 物,肉厚 $(\mathrm{Fe}) 10 \mathrm{~mm}$ 以下二於テ， $\mathrm{i}$ 週用ス。
符6 條 L針金型蒚滇ダージフ八總ベテノ X楾

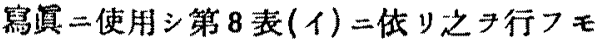
八下.

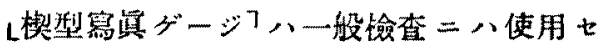
ズ，重要洁品ニシテ特二必要ト認ォタル場

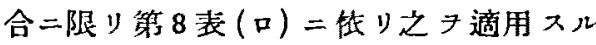
モノト

第 7 條 焦點距離ハ總べテ 60〜80 cm ニ於テ

第 6 表

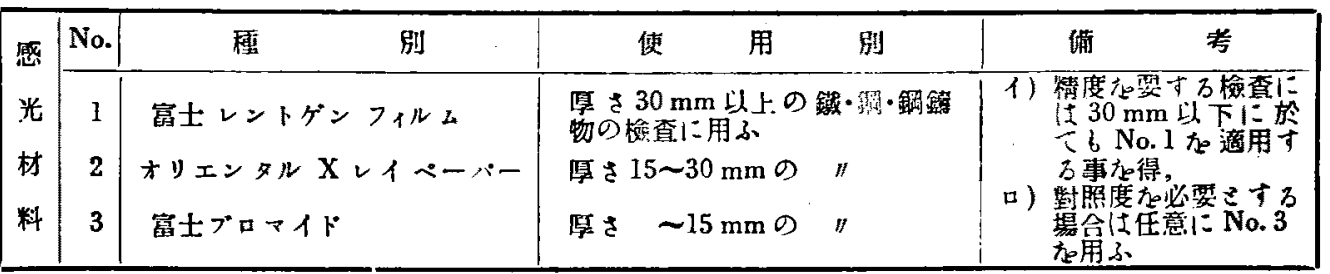

第 7 表

\begin{tabular}{|c|c|c|c|c|}
\hline \multirow{3}{*}{ 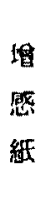 } & No. & 理 & 醂 & 䇶 \\
\hline & 1 & 使用する埭合 & 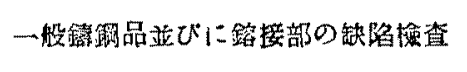 & \multirow{2}{*}{ 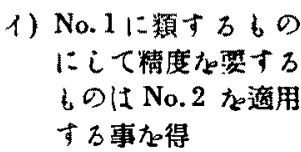 } \\
\hline & 2 & 使用さざ掍合。 & 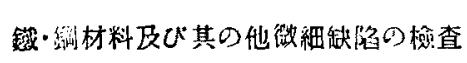 & \\
\hline
\end{tabular}

第 8 表 (1)

\begin{tabular}{|c|c|c|c|}
\hline 㝠 & 针金の太さ (Fe mm $\phi)$ & 被鲋查品の庆厚 $(\mathrm{mm})$ & 要 \\
\hline $\begin{array}{l}\text { 宾 } \\
\text { ゲ }\end{array}$ & $0.2 / 0.3 / 0.4$ & $\sim 3 v$ & \multirow{2}{*}{ 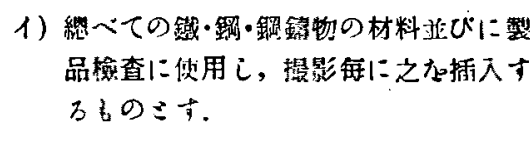 } \\
\hline : & $0.5 / 0.7 / 1.0$ & $30 \sim 60$. & \\
\hline
\end{tabular}

第 8 表 （口）

\begin{tabular}{|c|c|c|c|c|}
\hline & No. & 楔 装 ゲ 一 & 寸法 (mm) & 姴 \\
\hline 冒 & 1 & 22 & $\begin{array}{l}a=70 \\
b=20\end{array}$ & \multirow{2}{*}{ 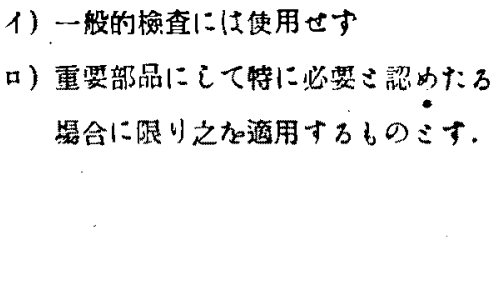 } \\
\hline$\forall$ & 2 & 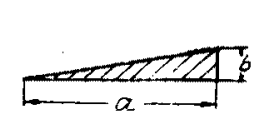 & $\begin{array}{l}a=70 \\
b=10\end{array}$ & \\
\hline
\end{tabular}


操作スルモノトス。

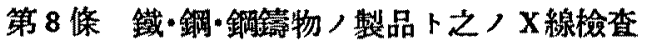

ノ方法八特別ナル埸合ノ外第 9 表二準ジテ 行フモノトス。

第 9 表

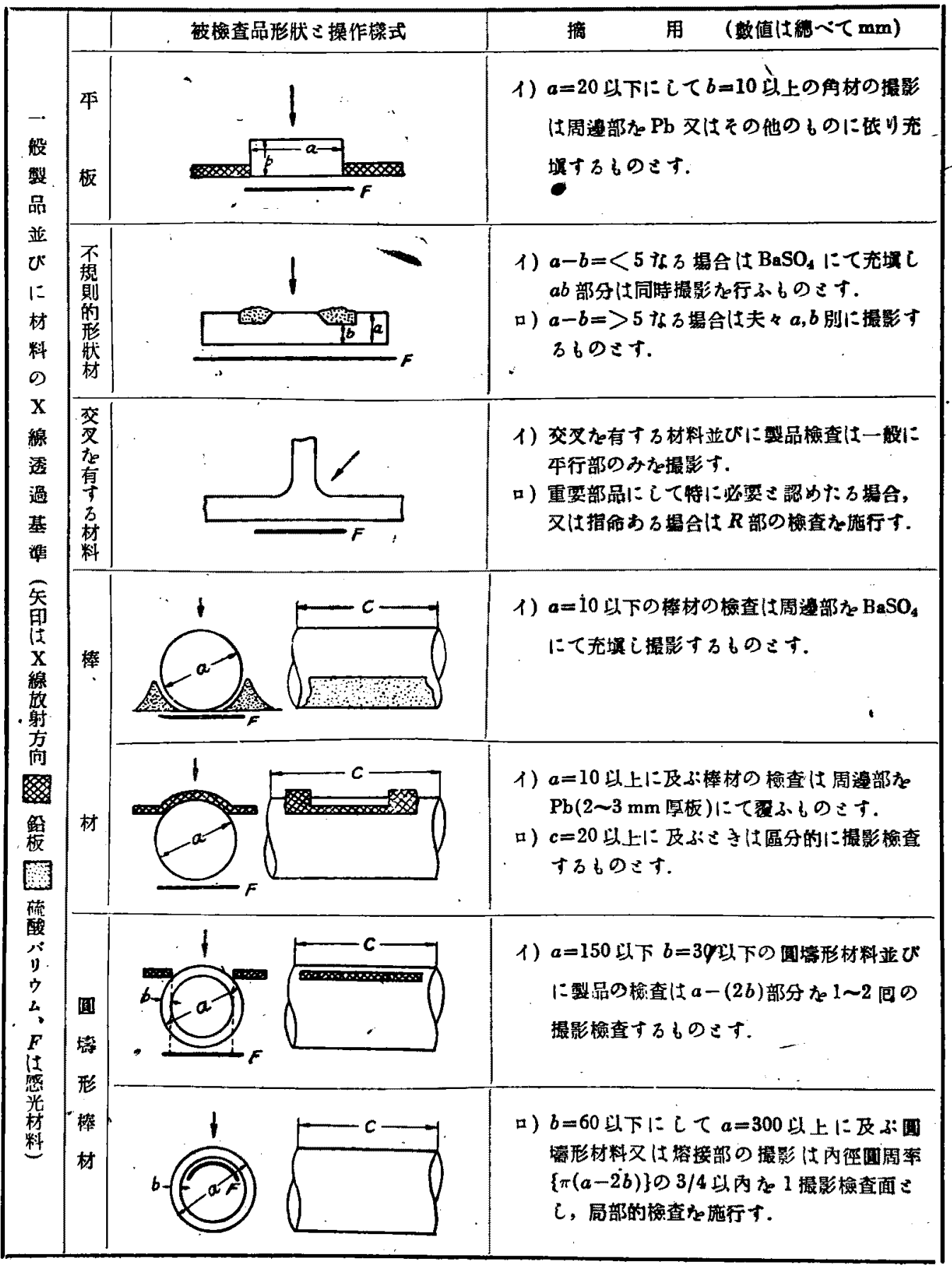

